prof. dr hab. inz. Jerzy Merkisz

Poznań University of Technology

Faculty of Working Machines and Transport

dr Wlodzimierz Stawecki, prof. IPS

Rail Vehicles Institute „TABOR” in Poznań

\title{
Environmental aspects of rail vehicles with combustion engines
}

\begin{abstract}
This paper covers the environmental issues related to the operation of rail vehicles. The evaluation of the environmental impact is based in most cases on a comparison of the current state of the internal combustion engine (its emissivity) with emission limit values of harmful exhaust components. These values relate to specific emission tests for engines or vehicles. For the national rail vehicles operating conditions these requirements take a slightly different form, as having a wide range of rolling stock markedly alters the environmental impact of these vehicles. Thus it becomes necessary to consider the issue of the method of evaluation of engine emissions in rail vehicles in terms of their actual operating conditions. Thus, efforts to assess the actual level of emissivity for rail vehicles and attempts to improve it are necessary and justified.
\end{abstract}

\section{INTRODUCTION}

Due to their advantages internal combustion compression ignition (CI) engines with direct injection remained the main source of power for rail vehicles. However, the harmful effect of these engines on the environment is significant (Fig. 1). Many types of combustion engine powered traction vehicles are used in Poland, many of their engines do not meet the requirements and criteria for exhaust emissions [12, $13]$.

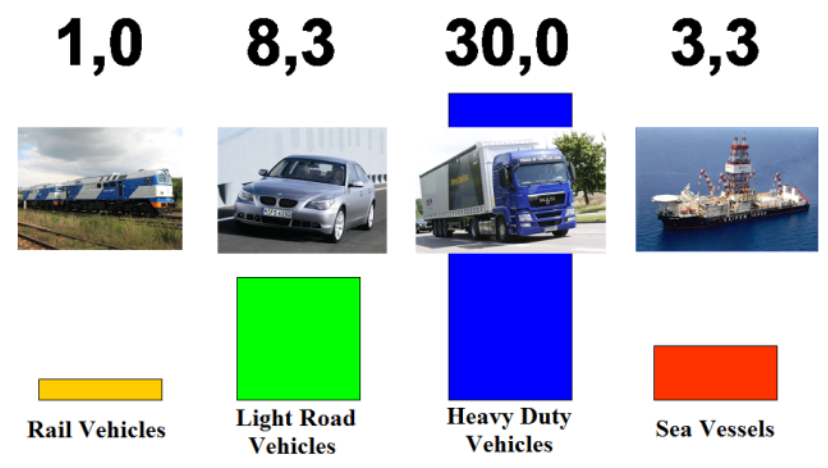

Figure 1. The relative environmental impact of different modes of transport

Effect of diesel locomotives on the environment depends on the nature of their work. The operating conditions of locomotives determine the specific fuel consumption and thus the emission levels. The share of operating time for a shunting locomotive spent in conditions of idling is $51.6 \%$ of the total operating time, $33 \%$ of the total operating time corresponds to $10 \%$ of the rated power output, while the remaining shares are negligible.
Ecological evaluation of diesel traction is very unfavorable compared to the electrical rail traction (Fig. 2). The amount of environmental damage caused by combustion engine vehicles of the rail traction in Poland during freight is 4 times higher than the damage caused by electric rail vehicles, and 1.8 times higher than for inland waterway vessels, however, still 5 times lower than the damage caused by trucks with diesel engines (especially in terms of particulate emissions [7]). The emissions of harmful compounds contained in the exhaust of off-road sources, which include combustion rail vehicles, represents a significant share with respect to road vehicles.

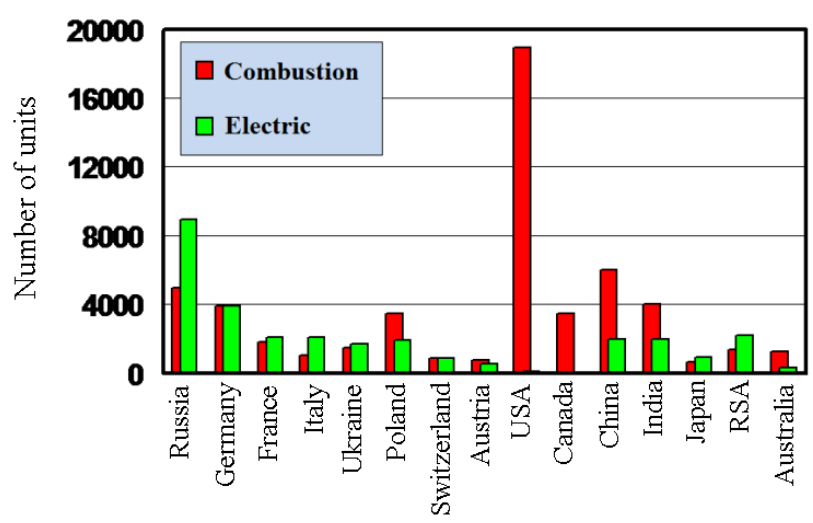

Figure 2. The share of diesel and electric locomotives in rail transport in individual countries 


\section{DIESEL LOCOMOTIVES IN PASSENGER AND CARGO TRANSPORT IN POLAND AND IN THE WORLD}

A characteristic feature of passenger locomotives is that they are designed to pull passenger and express trains. They have a source of energy for heating the train in the period of low temperatures (boiler heating systems, heat generators). Passenger locomotives also have a specific traction characteristic, especially in terms of speed. Freight locomotives do not have a source of energy for heating the train, and the traction characteristics should be adjusted to high loads at low speeds. Universal locomotives have both the qualities of freight and passenger locomotives.

Shunting locomotives are designed to pull or push (marshalling) wagons on tracks, sidings and in hump yards. One can also distinguish industrial locomotives, which are basically shunting locomotives, only some of which work in specific conditions, such as very high air pollution (e.g. in steel mills, coal sorting plants and mines) and elevated temperature (e.g. in steel mills during the transportation of the products of metallurgical process). Due to the type of transmission used, i.e. the method of moving and adjusting the torque of the internal combustion engine onto the driving wheelsets, three types of locomotives are distinguished: with mechanical transmission, hydraulic (hydrostatic, hydrodynamic) transmission and electric transmission (DC, AC).

The significant share of this type of internal combustion traction vehicles in the world undoubtedly also stems from the benefits of this mode of transport. Diesel locomotives have the following characteristics that are favorable compared to electric locomotives:

- power supply independent of an external source, which is important in case of natural disasters, in emergency situations; diesel locomotives can fully replace electric locomotives,

- the possibility of applying innovations in diesel locomotive drive system, different ways of power conversion and processing, different types of electric transmission,

- the ability to operate the locomotives even in difficult weather conditions, which could pose a significant impediment to electric locomotives,

- higher efficiency of diesel traction $\left(\eta_{0}=\right.$ $0.26)$ than the electric traction $\left(\eta_{\mathrm{o}}=0.21\right)$.

The Polish State Railways are currently operating 12 diesel locomotive series of standard gauge with combustion engine power outputs from $110 \mathrm{~kW}$ to $2200 \mathrm{~kW}$ (Fig. 3 and 4). Every year the number of diesel locomotives, both in the European Union and in Poland, is decreasing as a result of being replaced by electric locomotives (which have lower operating costs on lines with heavy traffic).

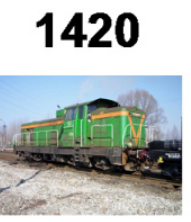

4-cycle

diesel engine

(a8C22)

1965

SM42

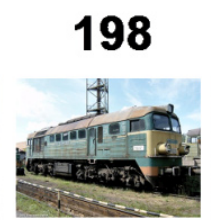

2-cycle

diesel engine

(14D40)

1966
149

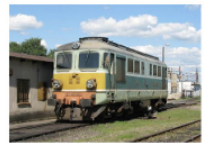

4-cycle

diesel engine

(12LDA28)

1965

ST43

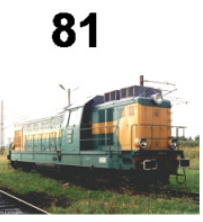

4-cycle

diesel engine

(M820SR)

1987
Figure 3. The rolling stock of combustion engine locomotives in Poland

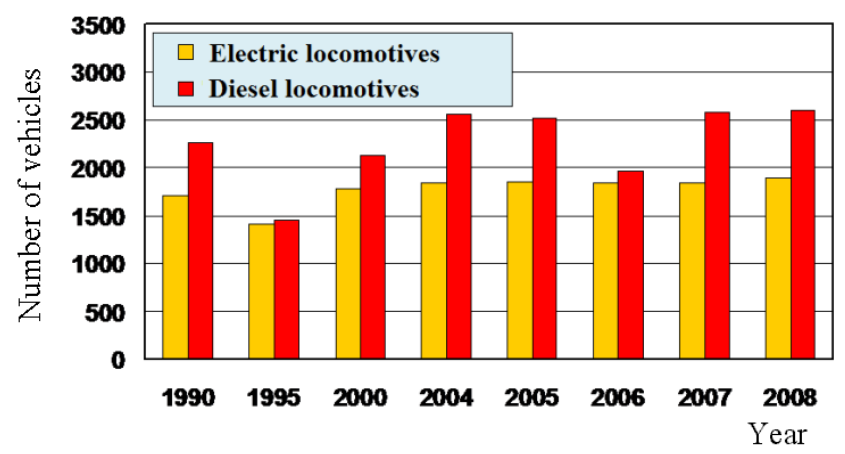

Figure 4. Electric and diesel locomotives in Poland

By 2020 the number of locomotives in Europe will decrease, but the number of diesel multiple units for the support of local passenger services will increase. UIC (International Union of Railways) analysis shows that by 2020 companies are planning to buy about 9000 new locomotives and 8500 diesel multiple units.

The characteristics of internal combustion engines of locomotives used on railway lines in the US is significantly different from their European counterparts. The US currently employs 21000 diesel locomotives with a mean power of 3467 HP. The large majority of locomotives $(61 \%)$ has engines with power of 4000-4400 HP installed. Internal combustion engines are built as medium-speed engines with large a displacement (e.g. GE engine with a capacity of 4400 HP). Modern European designs are highspeed engines with relatively small displacements. Engines with power above $2700 \mathrm{HP}$ account for only $9 \%$ and engines with low power (to $750 \mathrm{HP}$ ) account for about $28 \%$ of the market share. The remaining $63 \%$ are medium power engines with the power range of $750-2700 \mathrm{HP}$. Due to the larger cylinder displacements and lower engine speeds of locomotives operating in the US the emission levels from these engines may be lower. This concerns mainly the emissions of nitrogen oxides (lower combustion temperature, in particular the flame front), and the ability to accurately control fuel delivery (important aspect is the time required to burn the injected fuel dose). Despite the favorable working conditions of 
locomotive engines in the US attempts to limit their emissions of particulates began much earlier. The first attempts to apply filters were imposed by the EPA through the introduction of strict regulations for exhaust emissions from off-road vehicles. In Europe, the first attempts to use particulate filters have been taken in Switzerland and Germany (2004-2006).

The development of locomotives in the field of new fuels for combustion engines is in line with the development trends of combustion drives of road vehicles and other off-road means of land transport, and is consistent with changes that are currently observed in the air transport [10]. Their development will depend on the development of new technologies in land and air transport, and will follow in the direction of advanced propulsion technology for locomotives, which will ensure the best use of the energy supplied to the vehicle while maintaining high safety of completing the transport task and low emission factors $[3,6,8,9]$. Trends in the development of diesel locomotives will be characterized by the desire to:

- use modern combustion units in new and currently operated locomotives,

- increase the power output of the engine with unchanged fuel consumption,

- reduce harmful emissions and noise,

- reduce heat emitted from the diesel engine,

- design optimization of auxiliary engine equipment with regards to fuel consumption and manufacturing costs,

- design and develop diesel-electric drives for locomotives and to adapt these drives to cooperate with other systems in locomotives,

- develop electric drives with a new generation of batteries and electric motors,

- design and develop biofuels for use in diesel and diesel-electric locomotives for different transport tasks and industrial applications.

The increase in use of microprocessor technology in vehicles indicates that diesel locomotives will be increasingly equipped with such systems, both for engine control, security systems as well as locomotive diagnostics which, in the final version, will be realized by on-board diagnostic systems similar to the OBD systems used in road vehicles.

European emission regulations concerning rail traction engines: for locomotives (including shunting locomotives) and rail buses are outlined in UIC 624. The emission limit values were established in 2001 and they apply to newly manufactured diesel engines for rail vehicles. The currently designated test is an ISO 8178-F. These regulations do not apply to special locomotives (operated at a refinery or a mine) and traction motors with the power output of less than $100 \mathrm{~kW}$. It is worth noting that since 2008 the UIC limits are close to the limits of the Euro Stage IV standard $[1,2,11]$.

\section{AIM OF THE RESEARCH}

Assessing the impact of vehicles used for national railways requires the knowledge of actual emissions of harmful components for these vehicles. This task cannot always be realized in the form of tests according to relevant provisions, due to the different operating conditions of rail vehicles, because there are different conditions for the same locomotive (engine) used for the transport of passengers and goods.

The aim of the study was to determine the environmental impact of rail vehicles and to set directions for changes that would allow its reduction. The ecological situation of diesel rail vehicles is not satisfactory. They cause a significant increase in environmental pollution (high emission of harmful components), taking into account the technically outdated internal combustion engines used in locomotives and rail vehicles operating on the national railway routes. Thus, the main task was to determine the directions of improvement of the environmental impact of diesel rail vehicles (not limited to locomotives only) using methods such as repairs, re-motorization and the replacement of rail vehicles with other vehicles that meet the required criteria.

\section{RESEARCH METHODOLOGY}

The research subjects were divided into several groups depending on the stage of research carried out. For the analysis of the current state of emissions; tests of presently operated rail vehicles in the form of diesel locomotives were performed:

- for passenger transport: locomotives: SP32, ST43, SU45, SU46 and SP42,

- for cargo transport: locomotives: ST43, ST44, M62, M62M, BR231 and BR232,

- for shunting: locomotive SM42.

The possibilities of using light rail vehicles are presented on the example of one/two-bodied DH1/DH2, two-bodied Y, and three-bodied MR railcars. The effects of substituting shunting locomotives with road-rail vehicles are based on the studies of road-rail tractor Orion Crystal 13. Research of emissions of light rail vehicles cannot be carried out on a water resistor due to the hydrokinetic torque converter used in these vehicles. In these cases a mobile laboratory was used, allowing for emission measurements to be made anywhere on the track.

\section{RESULTS}

\subsection{Analysis of current emissivity and develop- ment of new testing methods}

Determination of the share of operating time of parameters for diesel locomotive engines shows that, in most cases, locomotives working in passenger transport: 
a) according to the ISO $8178-\mathrm{F}$ test a substantial amount of operating time of the locomotive is spent on idling; therefore, it is appropriate to give point 1 (which indicates idling in the certification and control tests) a significant share $u_{i}$ of this work phase;

b) in the remaining work phases of the combustion engine it is impossible to determine regions which could suggest the selection of the point of maximum power for measurements in tests; evaluation of operating time shares does not confirm the occurrence of notable shares of the highest settings of the power controller during passenger transport; hence replacing that point with several intermediate points is advisable.

c) intermediate settings of power controller are close to the certification test; which indicates that the intermediate points can correctly reproduce real traffic conditions, assuming a larger number of points is used (the research was not restricted to only one intermediate point).

Observations on the operation of internal combustion engines and their loads in shunting locomotives:

a) prevalence of time spent idling;

b) small shares of operating time at partial loads indicate a need for adjustments in the engine test, due to a significant disparity of the certification test results compared with the real engine operating conditions;

c) the absence of maximum engine loads during shunting operations of the locomotives - which makes it impossible to match the ISO 8178 test to the combustion engine's operating conditions and thus makes determining the extent of the locomotive's environmental performance in real operating conditions impossible.

Analysis of the operation of locomotives in freight traffic conditions leads to the following conclusions:

a) it is appropriate to consider the idling conditions in engine tests, as the analyzed locomotives will typically often utilize idling in their operating time (about 40\%);

b) in both cases partial loads are used in a small operating range, it is thus not necessary to incorporate the results of this testing phase in any significant proportion;

c) operating time under maximum load is significant for both locomotives; which indicates the necessity of taking these operating phases into account when constructing engine tests.

Knowledge of the load histograms of individual locomotives allows for the development of tests and determining the relation of the loads with respect to the current certification test. Due to the different traffic conditions for locomotives working in the movement of people and goods, as well as other traffic maneuvering (with or without hump) it became necessary to arbitrarily choose the selection of work phases and their operating time share. Due to the existence of set ranges of engine speed (power controller setting), as well as their resulting values of engine power, it is assumed that continuous functions do not comply with the conditions of selection of operating points in developing a new test. The operating conditions of each of the locomotives are discrete, not continuous. This results in having no ability to control (choose) the engine speed or power, which is not allowed due to the method of controlling the operating parameters of the engine. This analysis allowed for the establishment of the requirements that are to be met by a new test, while also complying with several conditions (Fig. 5):

a) due to different operating conditions the idea of designing a single engine test for all diesel locomotives was abandoned (such a simplification would not allow for determining the real working conditions of diesel locomotives),

b) the number of phases is not limited to three as it is the case in certification tests; their number depends on the number of settings available on the power controller - for the purposes of this research that number was assumed to be in the range of 3 to 6 ,

c) the test should take idling phase into account, because it has a significant share of operation time in the operating conditions for all types of locomotives (passenger transport, freight transport and shunting),

d) the choice of test phases should include the possibility of combining adjacent (or grouped) operating points (settings of the power controller),

e) the share of each operating point included in the new test should reflect the shares of operating time for each power controller setting.
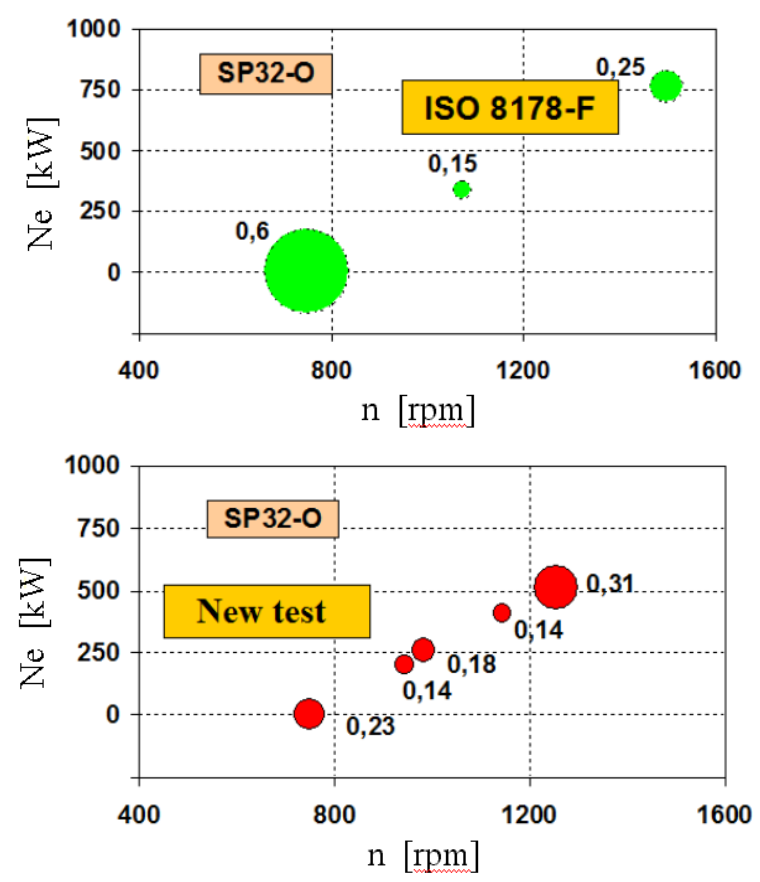

Figure 5. Comparison of existing and newly developed engine tests 
A comparison was made for exhaust emissions of a locomotive, whose histogram is shown above. The obtained results show that the emission values obtained by the new test are lower than those in the standard test. The new test shows the actual values obtained based on the work of the locomotive. Emissions from the locomotive (regardless of the type of test) exceed acceptable limits in terms of carbon monoxide and hydrocarbons. This indicates a substantial level of wear of the internal combustion engine. Lower values of NOx indicate that the obtained maximum power is lower than stated in the manufacturer's catalog data (Fig. 6). A similar analysis was made for a shunting locomotive. Emissions of $\mathrm{CO}$ and $\mathrm{HC}$ are much lower in the new test than in the standard test [4]. The specificity of operation for this locomotive is a significant share of engine operating time spent idling. But even in this case the emissions significantly exceed the limits outlined in the UIC 623 standard (Fig. 7).

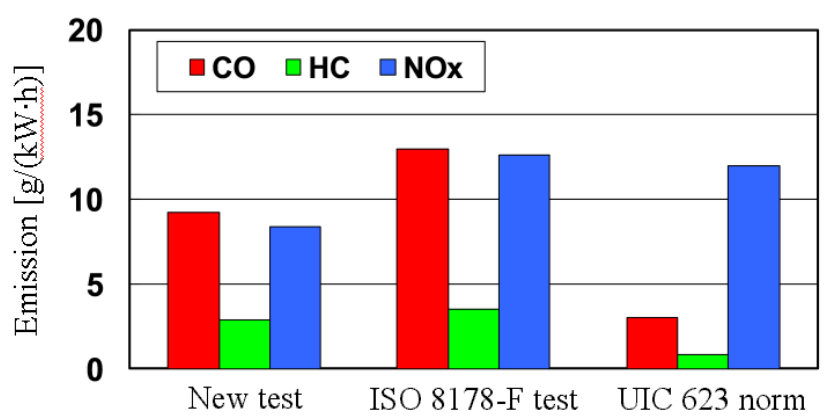

Figure 6. Exhaust emissions under real operating conditions of railway vehicles - a passenger locomotive SP32

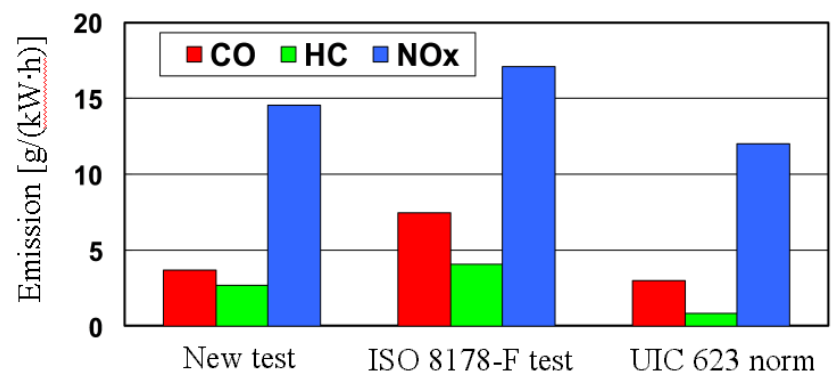

Figure 7. Exhaust emissions under real operating conditions of railway vehicles - shunting locomotive SM42

\subsection{Possibilities of emission reduction}

In order to determine the effect of the set operating parameters on the environmental indicators for combustion engines of rail vehicles; measurements of exhaust emissions were performed in relation to the changes in the crankshaft angle at fuel injection in the engine of a M62M locomotive. The study of variation in settings of the fuel injection system was carried out using discrete changes in the crankshaft angle at the start of fuel stamping for all twelve cylinders. Exhaust emission measurements were made by increasing and decreasing the angle by $\alpha= \pm 4^{\circ}$ of crankshaft rotation with the accepted incremental value equal to $\Delta \alpha=2^{\circ}$ of crankshaft rotation (Fig. 8). Opportunities to achieve a reduction in emissions, mainly nitrogen oxide emission, can be noticed. Additionally, the emission results at standard settings have been identified in order to determine the level of emissions from an engine of a newer design. The results indicate that in the case of engines whose emissions are close to current requirements changing the settings of the injection system is important and useful [5].

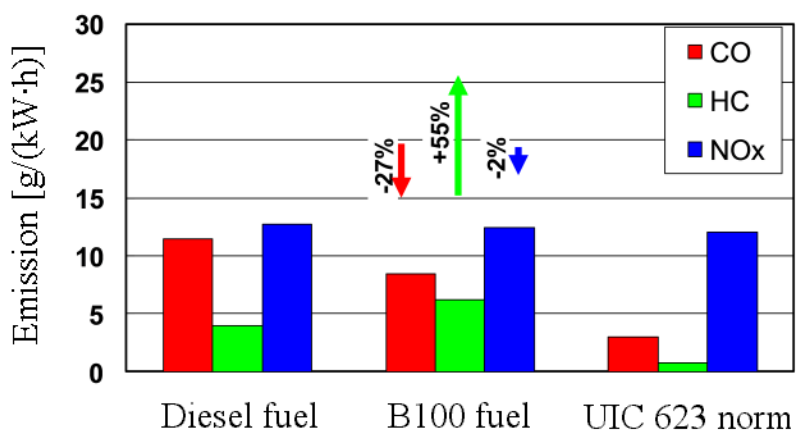

Figure 9. Comparison of emission from different fuels to the norm for diesel locomotives

Major repairs of diesel locomotives allow for partial reduction of emissions of hazardous components: the values obtained meet or exceed the ORE B13 standards, as well as the UIC standard (only for carbon monoxide emission). This allows for determining whether the boost pressure is correct or the value is maintained too high (suggested by the high NOx emission). $\mathrm{HC}$ emissions increase could be caused by insufficient run-in of the engine, but the result far exceeds the acceptable limits of the UIC standard. The injection process (injection timing) has been improved, as evidenced by the lower nitrogen oxide emission value, allowing compliance with the ORE B13 standards (Fig. 10).

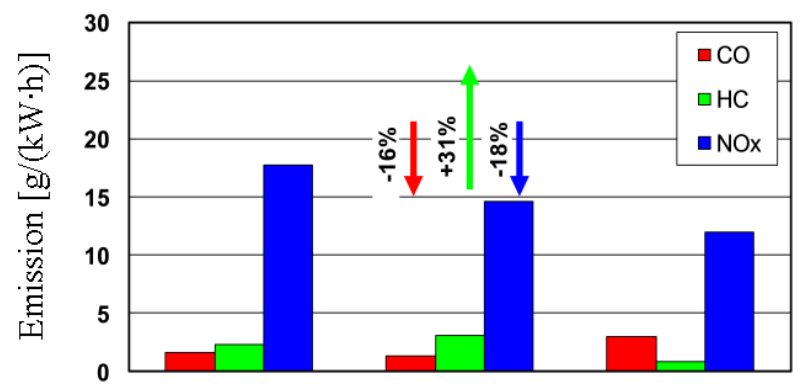

Before repairs After repairs UIC 623 norm

Figure 10. The effects of engine repairs on emissions of freight locomotive ST44

Changing the engine type leads to significant environmental benefits. Compared to the standard 14D40 engine, a reduction of hourly emissions of carbon monoxide by more than $80 \%$ was achieved. Hydrocarbon emissions were reduced by $36 \%$. While there was a $4 \%$ increase in nitrogen oxide emissions the $645 \mathrm{E} 3 \mathrm{~B}$ engine has more than $50 \%$ more power than its predecessor (Fig. 11). 


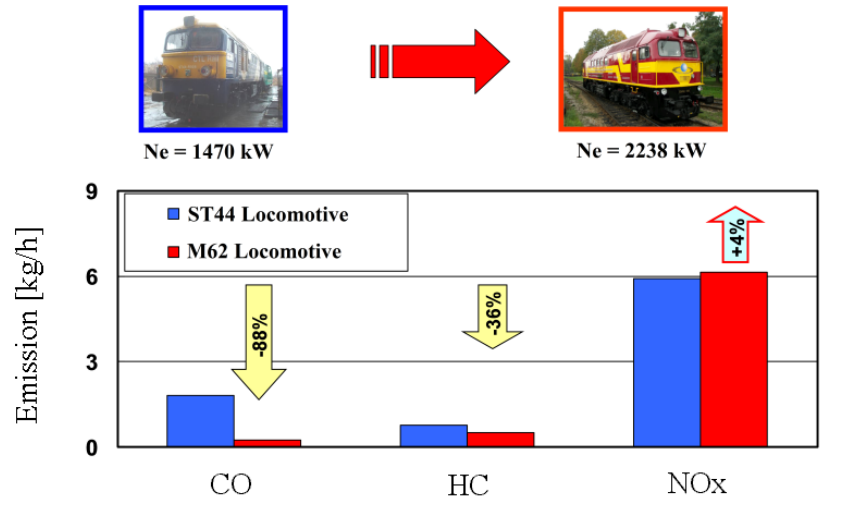

\subsection{Replacing diesel locomotives with light rail vehicles}

The range of regulatory changes in the engines, their repairs and re-motorization presented in previous chapters does not exhaust the possibilities of emission reduction for the engines of rail vehicles. Internal combustion engines of diesel locomotives mainly consist of worn-out high power engines. These engines often do not meet the emission limits for toxic components. They are often subject to additional regulations or major repairs aimed at improving their environmental performance. The situation with regard to the engines of light rail vehicles, including rail buses, is slightly different. They use heavy duty types of vehicle engines - loaded diesel engines with displacement volumes not exceeding $25 \mathrm{dm}^{3}$.

Due to the possibility of replacing worn-out diesel locomotives operating in passenger traffic the environmental indicators of rail buses were presented. The one-, two- or three-bodied traction rail vehicles currently imported into our country allow for significant reduction of emission of harmful ingredients. As a result of performed research it is possible to obtain more than $90 \%$ reduction in emissions of carbon monoxide when using these vehicles. Thanks to the newer engines used in those vehicles it is possible to reduce emissions of hydrocarbons anywhere between 70 to over $90 \%$. Emissions of nitrogen oxides would be reduced by almost $50 \%$ in the worst case scenario. It is also possible to reduce it by more than $95 \%$ (Fig. 12).
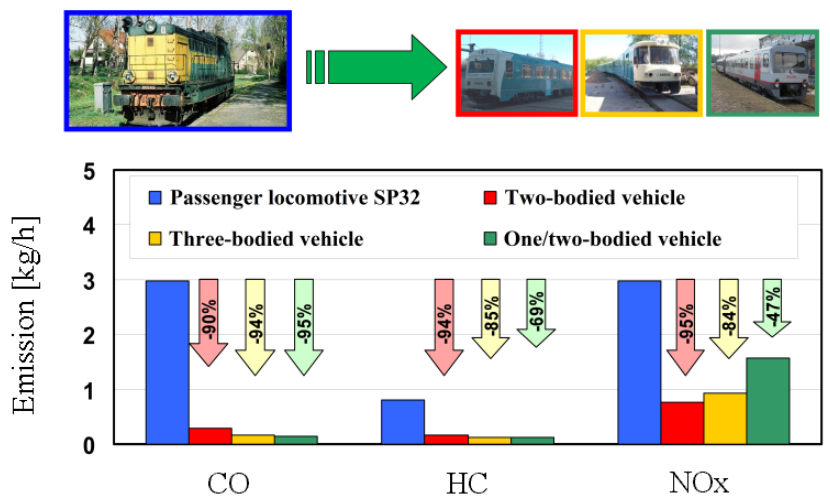

Figure 12. Emission impact of proposed changes in the rolling stock
SM42 type locomotives, used mainly for shunting work, could be replaced by road-rail vehicles. Road and rail tractor is a tractor designed to work in shunting of wagons on tracks (both narrow and wide).

Emission tests were carried out by comparing the work of such a shunting locomotive and a roadrail tractor with a capacity of approximately $100 \mathrm{~kW}$. Due to the different values of tractive force of these vehicles the exhaust emission analysis was performed by assuming that the operating time of road-rail tractor would be greatly extended. This analysis indicated the reduction of carbon monoxide emissions by more than $90 \%$. The hourly hydrocarbon emission is also more than $90 \%$ lower. Emission of nitrogen oxides is reduced under such conditions by more than $80 \%$. Measurements of particulate emissions were also performed and showed a $70 \%$ reduction in hourly emissions of particulate matter (Fig. 13).

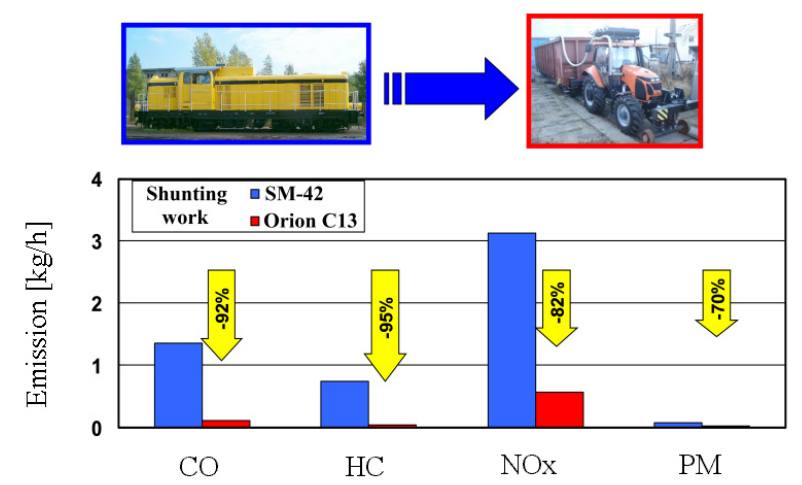

Figure 13. Replacing shunting locomotives with light rail vehicles

Utilizing the possibilities of emission reduction presented in this paper would require taking ecologically dominant directions in rolling stock development. For this purpose, these proposals are presented using as an indicator the percentage of change in the emission of harmful ingredients. The situation concerning the potential use of traction rail vehicles railcars seems very advantageous. Their use can offer nearly 4-fold reduction of the emissions of nitrogen oxides, 5-fold reduction of hydrocarbons, and up to 10 -fold reduction in carbon monoxide emissions (Fig. 14). Thanks to the presented solutions, it is possible to reduce the negative impact of exhaust emissions of rail vehicles on the environment.

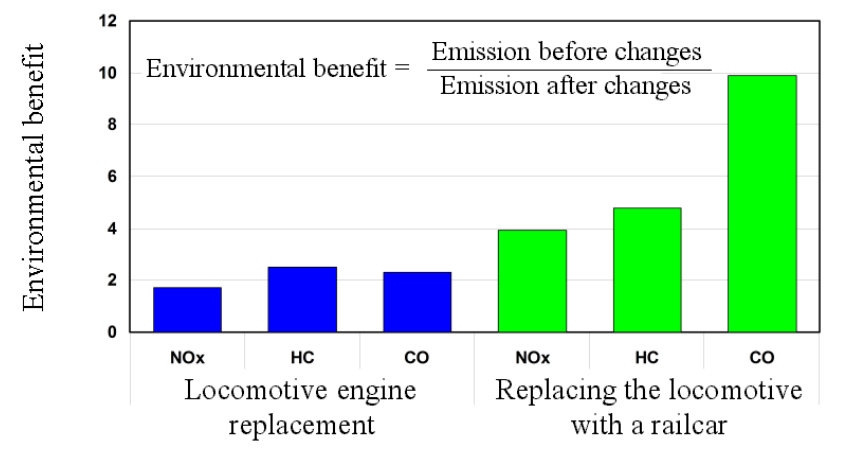

Figure 14. Environmental benefit: as multiples of ecological benefits offered by the best available solutions 
The economic benefits of utilizing methods and means of limiting the adverse impact of rail vehicles on the environment include:

- $\quad 50 \%$ reduction of fuel consumption,

- $\quad 70 \%$ reduction of engine oil consumption,

- $\quad 60 \%$ increase in engine power,

- extending locomotive lifespan by at least 20

years,

- $\quad$ extending the time between overhaul,

- fault indicator decreased 2.5-fold,

- $\quad$ return on investment within a 10 year period.

Particularly beneficial are the economic effects of replacing shunting locomotives with road-rail vehicles (Fig. 15), which include:

- cost of purchase for a road-rail shunting tractor is a third of the price for the cheapest shunting locomotive,

- exploitation costs for a road-rail tractor are a sixth of the equivalent costs of a shunting locomotive,

- three-fold improvement in traction properties,

- the ability to drive the tractor without the need for a train driving license on all owned railway sidings,

- the possibility of mechanization of cleaning of the rail and tram infrastructure,

- the possibility of adapting used road vehicles for road-rail uses,

- the possibility of purchase on appealing financing terms.

Replacement of shunting locomotives with road-rail vehicles with a two-shift work day provides a return for the costs of purchase of this vehicle in less than two years.

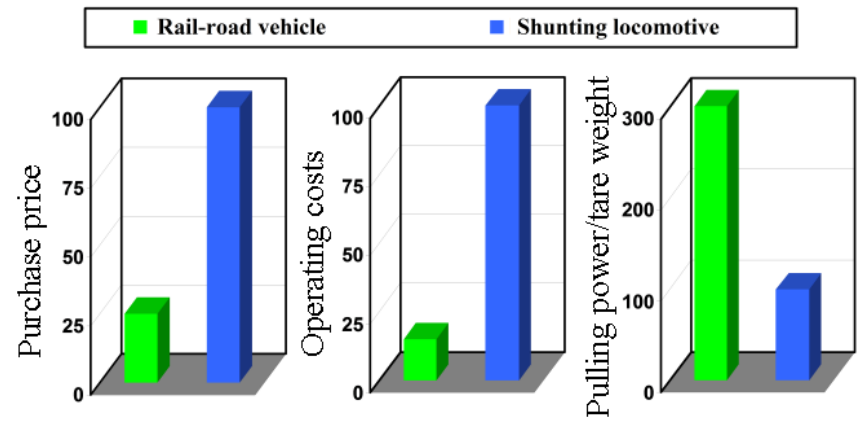

Figure 15. Comparison of advantages presented by a road-rail vehicle over a shunting locomotive

\section{CONCLUSIONS}

The presented possibilities of changes to the traditional rail vehicles in the form of modernization, replacement of internal combustion engines with more modern units, use of alternative fuels, use of railcars and special vehicles (road-rail tractors) all required finding the ecologically dominant directions. Understanding the impact of rail vehicles on the environment requires an assessment of their real traffic conditions, as well as the need to define exhaust emissions under these conditions. This is possible only after taking into account their specific operation. This task is made even more complicated by the fact that the locomotives do not have the same load histogram - dynamic operating conditions generate different emission values. In order to get the full "picture" of the ecological status of internal combustion engines a mobile testing laboratory for the measurement of exhaust emissions was developed.

Based on performed research it was found that it is possible to limit the negative effects of rail vehicles on the environment, under actual working conditions of these vehicles, which in turn allows the use of measures to reduce their environmental impact. The most effective method to reduce the impact of rail vehicles on the environment is the replacement of the engine unit and the replacement of diesel locomotives with light rail vehicles. Other methods of reducing emissions such as: engine control, use of alternative fuels, engine repairs, do not have the desired effect.

Specific conclusions:

1. The use of new tests for diesel locomotives operated in Poland is beneficial because it provides information on the real environmental impact of these types of locomotives.

2. According to a newly developed test the exhaust emissions for locomotives used in:

- passenger transport - is $20-40 \%$ lower for all exhaust components,

- $\quad$ shunting - is approx. $50 \%$ smaller,

- freight transport - no notable changes.

3. Replacement of diesel locomotives with light rail vehicles reduces the emissions of:

- carbon monoxide by $90-95 \%$,

- hydrocarbons by $69-94 \%$,

- nitrogen oxides by $47-95 \%$.

4. The use of railcars compared to diesel locomotives can result in:

- 10-fold carbon monoxide emission reduction,

- 5-fold hydrocarbon emission reduction,

- 4-fold nitrogen oxides emission reduction.

This study did not exhaust the issues related to the environmental aspects of rail vehicles. Further studies are to be conducted in the fields of:

- research that determines the load histograms for new rail vehicles imported from abroad and put into operation,

- study of environmental pollution in real traffic conditions for rail vehicles (an equivalent of Real Driving Emissions tests for motor vehicles),

- determining the correlation of emission test results between both the standard tests and those proposed in this paper and the real exhaust emission values, 
- determining the particulate matter emissions of the remaining types of rail vehicles (especially locomotives which could be replaced with light rail vehicles) working in shunting and ancillary service conditions,

- analysis of uses of oxidation catalysts or particulate filters in diesel locomotives.

\section{RE F E R ENCES}

[1] Directive 2004/26/EC of the European Parliament and of the Council amending Directive 97/68/EC on the approximation of the laws of the Member States relating to measures against the emission of gaseous and particulate pollutants from internal combustion engines to be installed in non-road mobile machinery, 21.04.2004.

[2] ISO: Reciprocating internal combustion engines exhaust emission measurement - Part 1: Test-bed measurement of gaseous and particulate exhaust emissions. Draft International Standard ISO/DIS 8178-1.2, 1995.

[3] Kettner J., Moving Towards Sustainable Mobility a Strategy for 2030 and Beyond for the European Railway Sector. 12 UIC Sustainability Conference, Venice 2012.

[4] Marciniak Z., Stawecki W., Merkisz J., Pielecha I., Pielecha J., Możliwości modyfikacji taboru spalinowego $w$ celu zmniejszenia jego oddzialywania na środowisko naturalne. Technika Transportu Szynowego, 3, 2011, 43-48.

[5] Marciniak Z., Stawecki W., Pielecha I., Pielecha J., Ekologiczne aspekty spalinowych pojazdów szynowych eksploatowanych na krajowych liniach kolejowych. Logistyka, 4, 2010.
[6] Merkisz J., Pielecha J., Emissions and Fuel Consumption during Road Test from Diesel and Hybrid Buses under Real Road Conditions. IEEE Vehicle Power and Propulsion Conference (VPPC'10), Lille 2010.

[7] Merkisz J., Pielecha J., Nanoparticle Emissions from Combustion Engines. Springer Tracts on Transportation and Traffic, 8, 2015.

[8] Merkisz J., Pielecha J., Fuć P., Emissionsfaktoren aus PEMS-basierter RDE-Prüfung für Fahrzeuge aller Gewichtklassen/ $L D V$ and HDV vehicle exhaust emission indexes in PEMS-based RDE tests. Fortschritt-Berichte VDI. Rheine 12, Nr 783, Vol. 1, 240-265.

[9] Merkisz J., Pielecha J., Gis W., Exhaust Emission Results from Light Duty Diesel in a Road Tests. Automobiles and Sustainable Mobility, FISITA 2010 World Automotive Congress, F2010-A-045. Scientific Society for Mechanical Engineering (GTE), Budapest 2010.

[10] Merkisz J., Pielecha J., Radzimirski S., New Trends in Emission Control in the European Union. Springer Tracts on Transportation and Traffic, 1, 2014.

[11] Norma PN-EN ISO 8178-4, Silniki spalinowe ttokowe. Pomiar emisji spalin. Cykle badawcze silników o różnym zastosowaniu. Wyd. 1999.

[12] Pielecha I. Marciniak Z., Wplyw silników spalinowych pojazdów trakcyjnych eksploatowanych $w$ kraju na środowisko - próby $i$ badania oraz wytyczne dla redukcji emisji składników szkodliwych. Pojazdy Szynowe, 1, 2009, 34-43.

[13] Pielecha I., Pielecha J., Tendencje w przepisach dotyczacych emisji zwiazków toksycznych przez silniki spalinowe pojazdów szynowych. Pojazdy Szynowe, 1, 2005, 52-59. 